\title{
A ADMINISTRAÇÃO DO TEMPO LIVRE
}

Ricardo Musse

Livre-docente do Departamento de Sociologia da FFLCH-USP. Integra o Laboratório Karl Marx

na FFLCH-USP. São Paulo, SP. Brasil.E-mail: <rmusse@usp.br>

http://dx.doi.org/10.1590/ 0102-6445107-134/99

Em 25 de maio de 1969, em uma de suas últimas aparições públicas, Theodor W. Adorno proferiu uma conferência - transmitida pela "Rádio da Alemanha" e publicada em seguida na coletânea Stichworte - sobre o conceito e a prática do "tempo livre" (Freizeit) ${ }^{1}$.

À época, a discussão sobre as formas de ocupação do tempo que não é preenchido pelo trabalho foi impulsionada por determinadas características da conjuntura histórica, específicas da fase do capitalismo denominada, por alguns pesquisadores, "regime de acumulação fordista" ou, por outros, a "era da regulação keynesiana".

Implementou-se, nesse período, uma política de pleno emprego, principalmente na Europa, com seu "Estado do bem-estar", e nos Estados Unidos, palco da "sociedade afluente" - regiões e países favorecidos pelas assimetrias da divisão internacional do trabalho. Parte dos ganhos resultantes de aumentos de produtividade pode ser transferida

\footnotetext{
1 Adorno faleceu em 6 de agosto de 1969, durante as férias escolares. Pouco antes, em junho, encaminhou para edição os artigos que compõem o livro Stichworte: Kritische Modelle 2 (traduzido no Brasil como Palauras e sinais).
} 
para os trabalhadores sob a forma de benefícios e direitos sociais, efeito almejado de uma repartição pactuada dos fundos públicos.

A gradativa redução da jornada normal de trabalho, sinalizando e consolidando uma tendência de longo prazo, inspirou uma série de conjecturas acerca de uma possível mudança nas estruturas até então assentadas como próprias do mundo moderno. A conferência-ensaio de Adorno organiza-se, ao mesmo tempo, como uma atualização e como um comentário das considerações de Karl Marx acerca da situação do trabalho no capitalismo. Remete também, ainda que em menor medida, às ponderações de Max Weber que se tornaram um dos pomos de discórdia na controvérsia acerca da obsolescência ou não do paradigma da "sociedade do trabalho".

\section{Crítica e resignação}

108 No capítulo IV do livro primeiro de O capital (1867), Marx expõe o movimento de "circulação do dinheiro", definindo-o como a "fórmula geral" do modo de produção capitalista. O processo sintetizado na forma D-M-D ("transformação do dinheiro em mercadoria e retransformação da mercadoria em dinheiro") discrepa radicalmente de seu ponto de partida e pressuposto, a circulação de mercadorias. A diferença deve-se não só à alteração da finalidade - a "valorização do valor" configura um desenvolvimento muito distinto da troca cujo objetivo não ultrapassa o mero consumo, a satisfação de necessidades -, mas também concerne aos agentes sociais que impulsionam os dois procedimentos (Cf. Marx, 1984 [1867], pp. 125-31).

A figura do capitalista, um indivíduo que adota a acumulação monetária como meta subjetiva, operando como "capital personificado" - "dotado de vontade e consciência" -, constitui, segundo ele, uma condição tão necessária ao 
funcionamento do moderno processo de produção como a existência e disponibilidade do "trabalhador livre".

No capítulo XXIV de O capital, intitulado "A assim chamada acumulação primitiva”, Marx (1984 [1867], tomo 2, pp. 261-94) investiga a origem histórica do proletariado moderno. Procura reconstituir a gênese de uma massa de indivíduos proprietários de sua capacidade de trabalho (isto é, de sua pessoa), que não dispõem de outra mercadoria para vender a não ser sua força de trabalho.

Ele não deixa de chamar a atenção para as características bastante singulares do empreendedor capitalista. Descreve-o como um "entesourador racional”, que sacrifica os prazeres da carne ao fetiche do ouro, adotando como "virtudes cardeais" "a abstenção, a laboriosidade e a avareza", mas que, uma vez acumulado o capital, coloca-o incessantemente em circulação, visando à expansão infinda de sua grandeza (Cf. Marx, 1984, pp. 129-30). No entanto, Marx não se deteve ou mesmo não se preocupou em esclarecer o surgimento desse agente, tão decisivo para o funcionamento do capitalismo quanto distinto dos hábitos cristalizados em outras formas sociais de produção.

Max Weber considerou, no âmbito de suas investigações acerca da especificidade do capitalismo no Ocidente, o preenchimento dessa lacuna como um momento imprescindível. A ética protestante e o "espírito" do capitalismo (19041905), marco inicial dessa pesquisa, elegeu a compreensão do comportamento peculiar do empresário capitalista como um de seus eixos principais.

Etapa de um programa orientado para o estabelecimento de uma "tipologia" das modalidades de determinação da mentalidade econômica por crenças religiosas, e, em particular, pela busca de "correlações do ethos econômico moderno com a ética racional do protestantismo ascético" (Weber, 1996, p. 20), o livro procura mapear as afinidades existentes entre as concepções religiosas que 
emergiram no bojo da Reforma protestante e as máximas da vida econômica ${ }^{2}$. Nessa perspectiva, Weber observa que a exigência de ação conforme a vontade divina, implantada pelo puritanismo, desembocou na louvação da ocupação mundana, da ação metódica, mais precisamente, na glorificação do "trabalho profissional racional". Concomitantemente, desqualificou-se o ócio, o prazer de viver, a contemplação, o gozo e até mesmo a perda de tempo, concebidos como manifestações de uma forma de vida impura (Weber, 2004, pp. 143-58).

O desenvolvimento do "estilo de vida capitalista" teria sido, por conseguinte, influenciado diretamente pela "concepção puritana de vocação profissional” (Weber, 2004, p. 151). A mentalidade própria à exigência de uma conduta ascética modelou tanto o portador do capital, liberando-o dos entraves da ética tradicionalista para a busca e ampliação de seus ganhos, como o trabalhador, educando-o para 110 a regularidade e disciplina da produção. Nas palavras de Weber (2004, p. 161):

Surgiu um ethos profissional especificamente burguês. Com a consciência de estar na plena graça de Deus e ser por ele visivelmente abençoado, o empresário burguês, com a condição de manter-se nos limites da correção formal, de ter sua conduta moral irrepreensível e de não fazer de sua riqueza um uso escandaloso, podia perseguir os seus interesses de lucro e devia fazê-lo. O poder da ascese religiosa, além disso, punha à sua disposição trabalhadores sóbrios, conscienciosos, extraordinariamente eficientes e aferrados ao trabalho como se finalidade de sua vida, querida por Deus.

\footnotetext{
2 Como exemplo das normas típicas do "espírito" do capitalismo, Weber (2004, pp. 41-69) destaca trechos da Autobiografia de Benjamin Franklin, apresentados como uma espécie de sermão profano da "profissão como dever".
} 
$\mathrm{Na}$ "Introdução" aos Ensaios reunidos de sociologia da religião (de 1920) - uma breve meditação sobre o significado de uma das vertentes de sua obra -, Weber conecta suas investigações com a questão da especificidade do racionalismo ocidental. Conduziu essa tarefa, em parte, como uma contraposição aos procedimentos de racionalização forjados em outras civilizações, em especial na judaica, na hindu e na chinesa ${ }^{3}$. Entre outros desenlaces, a comparação entre as "éticas econômicas das religiões universais" teria possibilitado o delineamento de uma sociologia da "capacidade e disposição dos homens para determinadas formas de conduta prática e racional" (Weber, 1996, p. 20).

Os movimentos de racionalização no Ocidente, em suas esferas principais - economia, administração, política, direito, ciência e arte -, desenrolaram-se sob a forma de desenvolvimentos simultâneos e conexos, seguindo, no entanto, em paralelas, lógicas internas próprias e diferenciadas. Engendrou-se assim uma indeterminação que Weber (1972, pp. 41-43) qualificou

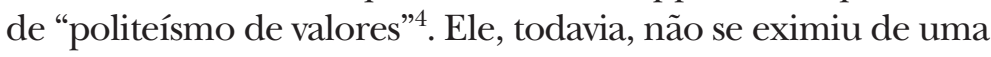
avaliação geral desses processos de longa duração, apresentada sob o diagnóstico de um "desencantamento do mundo".

Com esse conceito, Weber designa uma forma específica de racionalização, característica da sociedade ocidental, decorrente da combinação da eliminação progressiva da magia como "meio de salvação" com os efeitos da ciência moderna - considerada como o fragmento mais importante de um movimento multissecular de "intelectualização"5.

\footnotetext{
3 Weber (1996, p. 20) aponta o surgimento das "mais diversas formas de racionalização nos mais díspares espaços vitais e em todas as áreas culturais", listando como exemplos a racionalização da "contemplação mística, da vida econômica, da técnica, do trabalho científico, da educação, da prática jurídica e da administração".

4 "A vida [...] só conhece o combate eterno que os deuses travam entre si ou - evitando a metáfora - só conhece a incompatibilidade das atitudes últimas possíveis, a impossibilidade de dirimir seus conflitos" (Weber, 1972, p. 47).

5 Para um acompanhamento e comentário de todas as passagens em que Weber recorre ao conceito de "desencantamento do mundo", ver Pierucci (2003).
} 
Tal conjunção, ao reduzir o universo a mero "mecanismo causal" (noção confirmada, no âmago da religião reformada, pelo abandono de qualquer tentativa de "salvação eclesiástico-sacramental”), possibilitou a intensificação do domínio - por meios técnicos, bem como pelo cálculo e previsão - da natureza e da vida social ${ }^{6}$. Esse cosmos da "causalidade natural", despojado de pressupostos últimos, destituiu as prevalecentes "imagens de mundo" que o concebiam como uma ordem orientada eticamente.

Na conferência de 1917, A ciência como vocação, Weber conclui assim o trecho em que discute o valor e o significado dessa atividade para a vida humana:

Qual é afinal, nesses termos, o sentido da ciência enquanto vocação, se estão destruídas todas as ilusões que nela divisavam o caminho que conduz ao "ser verdadeiro", à "verdadeira arte", à "verdadeira natureza", ao "verdadeiro deus", à "verdadeira felicidade"? Tolstói dá a essa pergunta a mais simples das respostas, dizendo: ela não tem sentido, pois não possibilita responder à indagação que realmente nos importa - “Que devemos fazer? Como devemos viver?”. De fato, é incontestável que a resposta a essas questões não nos é tornada acessível pela ciência (Weber, 1972, pp. 35-36).

Com a expansão do capitalismo, a "profissão como vocação", exaltada pelo protestantismo ascético e componente decisivo na configuração do homo oeconomicus, assume outras funções, extravasando o âmbito estrito da autoconservação material, desdobrada em domínio técnico-prático

\footnotetext{
6 "Em princípio, a visão de mundo, tanto empírica como matematicamente orientada, apresenta refutações a qualquer abordagem intelectual que, de alguma forma, exija um significado para as ocorrências do mundo interior" (Weber, 1971, p. 401). Logo adiante, Weber (p. 408), no entanto, reitera que a perda de significado do universo tem dupla origem: "Não só o pensamento teórico, desencantando o mundo, levava a essa situação, mas também a própria tentativa da ética religiosa de racionalizar pratica e eticamente o mundo".
} 
da natureza. As investigações conduzidas por Weber destacam que o trabalho racional, metódico, tornou-se, para o indivíduo moderno, enquanto sucedâneo da ética religiosa num mundo desmagificado e esvaziado de sentido objetivo, a principal forma de orientação da conduta e de ação significativa na vida ${ }^{7}$.

Diferentemente da compreensão resignada de Max Weber, o marxismo se constituiu como uma crítica da sociedade do trabalho. Uma comprovação dessa atitude pode ser atestada pela presença, recorrente ao longo da obra de Marx, do tópico "alienação do trabalho".

Dentre os textos iniciais, redigidos na década de 1840, o comentário dessa questão não pode deixar de salientar os Manuscritos econômico-filosóficos (1844). Nesses cadernos, publicados apenas em 1932, Marx distingue duas modalidades de estranhamento do trabalhador: diante do resultado de seu trabalho e no "ato de produção, dentro da própria atividade produtiva” (Marx, 2004 [1844], p. 82) ${ }^{8}$.

Marx conecta a primeira dessas formas de alienação com determinados princípios, estruturantes da ordem social moderna. Ele observa que os produtos do trabalho, para além de sua existência como objetos externos, apartados do indivíduo, surgem também como algo "independente e estranho ao trabalhador, tornando-se uma potência autônoma diante dele". Assim, a "vida que ele concedeu ao objeto se lhe defronta hostil e estranha" (Marx, 2004, p. 81).

\footnotetext{
7 Nesse cenário, Hannah Arendt (1981, p. 12) assinala a emergência de uma flagrante contradição: "A era moderna trouxe consigo a glorificação teórica do trabalho, e resultou na transformação efetiva de toda a sociedade em uma sociedade operária. Assim, a realização do desejo [de libertação da "fadigas e penas" do trabalho], como sucede nos contos de fadas, chega num instante em que só pode ser contraproducente. A sociedade a ser libertada dos grilhões do trabalho é uma sociedade de trabalhadores, uma sociedade que já não conhece aquelas outras atividades superiores e mais importantes em benefício das quais valeria a pena conquistar essa liberdade".

8 Para um relato pormenorizado do tema "trabalho" nos Manuscritos, ver Marcuse (1972; 1978, pp. 252-64).
} 
Parte dessa hostilidade explica-se pelo fato de que o trabalhador não é proprietário dos resultados de seu trabalho, atributo essencial da produção de bens no capitalismo. Na exposição de Marx (2004, p. 80), porém, essa estranheza decorre também e principalmente da consideração de que "o trabalho não produz somente mercadorias; ele produz a si mesmo e ao trabalhador como uma mercadoria", movimento que redunda no seguinte paradoxo: "quanto mais objetos o trabalhador produz, tanto menos pode possuir e tanto mais fica sob o domínio de seu produto, do capital" (p. 81).

A alienação do trabalhador durante a produção, por sua vez, deriva do caráter "externo" de sua atividade, patente na constatação de que o trabalho no capitalismo consiste simplesmente em um meio para a satisfação de outras necessidades. Inserido nas malhas de uma ação compulsória, o trabalhador - conforme o diagnóstico dos Manuscritos econômico-

114 -filosóficos - "só se sente junto a si fora do trabalho e [sente-se] fora de si no trabalho" (Marx, 2004 [1844], p. 83) ${ }^{9}$.

Afora isso, no ato de produção, "o trabalho aparece para o trabalhador como se [...] não pertencesse a si mesmo, mas a um outro" (Marx, 2004, p. 83). O contexto dessa contradição, a situação na qual o trabalho, em oposição à sua definição clássica, não pode mais ser concebido como "autoatividade", encontra-se formulado numa passagem do Manifesto comunista (1848) em que Marx, após saudar a liberação de "colossais" forças produtivas "adormecidas no seio do trabalho social” (Marx, 2010a [1848], p. 63), comenta a condição do trabalhador no interior da grande indústria:

\footnotetext{
9 Algumas linhas adiante Marx exemplifica assim essa frase: "Chega-se, por conseguinte, ao resultado de que o homem (o trabalhador) só se sente livre e ativo em suas funções animais, comer, beber e procriar, quando muito ainda habitação, adornos etc., e em suas funções humanas só [se sente] como animal" (Marx, 2004, p. 83).
} 
O trabalho dos proletários perdeu, pela expansão da maquinaria e pela divisão do trabalho, todo caráter autônomo e, com isso, todo atrativo para o operário. Este torna-se um mero acessório da máquina, do qual é exigido apenas o mais simples movimento de mãos, o mais monótono, o mais fácil de aprender. [...] Massas de operários, aglomeradas nas fábricas, são organizadas de forma soldadesca. Como soldados rasos da indústria, são colocados sob a supervisão de uma hierarquia completa de suboficiais e oficiais (Marx, 2010a, pp. 66-67).

Marx qualifica o modelo de organização do trabalho na fábrica moderna de "despotismo". A submissão do trabalhador à gerência da produção é apresentada como um momento chave em sua enumeração das figuras da dominação social no capitalismo - "eles não apenas são servos da classe burguesa, do Estado burguês, diariamente e a cada hora eles são escravizados pela máquina, pelo supervisor e, sobretudo, por cada um dos fabricantes burgueses" (Marx, 2010a, p. 67).

No primeiro volume de $O$ capital, essa designação é retomada e generalizada com a definição, assertiva, da forma da direção empresarial capitalista como "despótica" ${ }^{10}$ Marx (1984 [1867], p. 265) sugere que somente o obscurecimento desse controle "encarniçado" possibilita a inversão por meio da qual a "força produtiva social do trabalho desenvolvida pela cooperação aparece como força produtiva do capital", e a própria cooperação - gestada "em oposição à economia camponesa e ao exercício independente dos ofícios" - passa a ser considerada um procedimento específico do processo de produção capitalista.

\footnotetext{
10 "Se portanto a direção capitalista é, pelo seu conteúdo, dúplice, em virtude da duplicidade do próprio processo de produção que dirige, o qual por um lado é processo social de trabalho para a elaboração de um produto, por outro, processo de valorização do capital, ela é quanto à forma despótica” (Marx, 1984 [1867], p. 263).
} 
De modo geral, no decorrer de sua obra, em especial nos textos de crítica da economia política ensaiados durante e após a década de 1850, Marx projeta a produção de bens no socialismo como o avesso da cooperação instituída sob o comando do capital ${ }^{11}$. Sua expectativa é de que numa "associação de homens livres" desapareça a superintendência despótica da atividade produtiva e, com ela, o trabalho reificado (Marx, 1984, p. 75).

Marx (2004, p. 83) delineia assim um cenário em que o metabolismo do homem com a natureza não seja mais vivenciado como "autossacrifício, mortificação", mas, ao contrário, desenvolva-se plenamente por intermédio da livre aplicação das energias humanas, físicas e espirituais. Na "fase superior do comunismo”, imagina Marx (1977, p. 233), uma vez ultrapassado "o estreito horizonte do direito burguês, a sociedade poderá inscrever em suas bandeiras: de cada um conforme sua capacidade, a cada um segundo suas 116 necessidades".

A recepção do capítulo VIII de $O$ capital, no entanto, forjou uma interpretação um pouco diferente da posição de Marx acerca da questão do trabalho no mundo moderno. Nessa parte do livro, ele condensa e exemplifica a luta de classes no capitalismo como um conflito em torno da jornada de trabalho:

O capitalista afirma seu direito como comprador, quando procura prolongar ao máximo a jornada de trabalho e transformar se possível uma jornada em duas. Por outro lado, a natureza específica da mercadoria vendida implica um limite de seu consumo pelo comprador, e o trabalhador afirma seu

\footnotetext{
${ }^{11}$ Antes de estabelecer a forma expositiva e o escopo de $O$ capital, Marx redigiu uma série de esboços, dos quais editou apenas Para a crítica da economia política, em 1859. Os Grundrisse (1857-1858) e os Manuscritos de 1861-1863 foram publicados somente no século XX. Para um relato dos planos de trabalho elaborados por Marx no período, ver Rosdolsky (2001, pp. 27-60).
} 
direito quando quer limitar a jornada a determinada grandeza normal. Ocorre aqui, portanto, uma antinomia, direito contra direito, ambos apoiados na lei do intercâmbio de mercadorias. Entre direitos iguais decide a força. E assim a regulamentação da jornada de trabalho apresenta-se na história da produção capitalista como uma luta ao redor dos limites da jornada - uma luta entre o capitalista coletivo, isto é, a classe dos capitalistas, e o trabalhador coletivo, ou a classe trabalhadora (Marx, 1984, p. 190).

A inserção desse capítulo na terceira seção do primeiro volume, intitulada "A produção da mais-valia absoluta", por si só indica que a disputa principal gira em torno da taxa de mais-valia, uma grandeza que pode ser aumentada ou diminuída conforme a extensão da jornada diária de trabalho. O capítulo, porém, um dos mais longos de $O$ capital, envereda por outros assuntos. Desdobra-se como uma narrativa histórica recheada de informações e estatísticas e, ao mesmo tempo, como um libelo contra os abusos impingidos aos trabalhadores durante e após a Revolução Industrial inglesa.

O decisivo, entretanto, consiste no fato de que foi recebido também como um relato da formação da classe operária, numa notação distinta do itinerário delimitado no Manifesto comunista. A maioria dos teóricos da Segunda Internacional compreendeu essa exposição como uma nova versão, substancialmente alterada, de um percurso no qual se mapeia uma trajetória de constituição do proletariado que não desemboca na ação revolucionária. Esse juízo permitiu que Marx fosse apresentado como fiador de um programa político cujo objetivo primordial consiste na redução da jornada de trabalho.

Algumas passagens de $O$ capital prescrevem a ampliação do tempo livre como pré-condição indispensável ao fortalecimento material e intelectual dos trabalhadores. No trecho 
citado a seguir, por exemplo, recorrendo à sua figura literária predileta, a ironia, Marx destaca os interesses do proletariado por intermédio de uma contraposição à perspectiva do capital, segundo a qual,

[...] o trabalhador, durante toda a sua existência, nada mais é que força de trabalho e que, por isso, todo o seu tempo disponível é por natureza e por direito tempo de trabalho, portanto, pertencente à autovalorização do capital. Tempo para educação humana, para o desenvolvimento social, para o jogo livre das forças vitais físicas e espirituais, mesmo o tempo livre de domingo - e mesmo no país do sábado santificado - pura futilidade! (Marx, 1984, p. 211).

É mais plausível, tendo em vista o espírito de sua obra, que Marx esteja, mais uma vez, indicando características próprias do "reino da liberdade" como o negativo da situa118 ção vigente no capitalismo. Todavia, a indeterminação desse e de outros trechos semelhantes não deixaram de contribuir para fornecer credibilidade às propostas elaboradas no campo da Segunda Internacional.

Além disso, as intervenções de Marx no âmbito da Associação Internacional dos Trabalhadores endossam, como estratégia preferencial da classe operária, os esforços para restringir legalmente a extensão da jornada ${ }^{12}$. Não resta dúvida de que ele considerava esse combate apenas como a primeira batalha na caminhada em direção a uma transição para o socialismo. Essa convicção, porém, não impediu que os sindicatos e, com eles, os partidos de massa da social-democracia transformassem a bandeira da redução da jornada de trabalho, seguindo o mote de Bernstein, de meio em meta principal da luta pela emancipação do proletariado.

12 Os documentos e os esboços referentes à Primeira Internacional, redigidos por Marx (e por Engels) foram agrupados entre os volumes 16 e 21 das Gesamtausgabe (Obras completas) (Marx e Engels, 1983). 


\section{0 lazer no capitalismo}

Em “Tempo livre", Adorno (1995a) ressalta de antemão que uma investigação pertinente da questão do trabalho no mundo contemporâneo deve introduzir uma nova variável, a qual se refere ao relativo sucesso do esforço dos sindicatos e da social-democracia em restringir a duração legal da jornada diária de trabalho. A esse êxito se acrescenta a possibilidade - inscrita no desenvolvimento, nem sempre utilizado, das forças produtivas - de ampliação ainda maior do tempo livre ${ }^{13}$.

A condução do debate nesses parâmetros não significa, no entanto, que a discussão deva ser desenvolvida no patamar da "generalidade abstrata". Ao contrário, alerta Adorno, as novas condições que emergiram com a diminuição paulatina do tempo despendido no trabalho, e a própria potencialidade entrevista no bojo de uma sucessão de descobertas e inovações, reforçam a demanda para que o exame do tópico "tempo livre" seja inserido no quadro de uma inquirição mais abrangente que não ignore as tendências fundamentais do sistema capitalista.

Essa exigência é sacramentada já na definição do termo. Afinal, nas palavras de Adorno (1995a, p. 70), "a diferença específica que o distingue do tempo não livre, aquele que é preenchido pelo trabalho", torna patente que "o tempo

\footnotetext{
13 Poucos anos após a publicação da conferência de Adorno, realizada em maio de 1969, sobre o conceito e a prática do "tempo livre", a configuração que pendia para uma redução gradual da duração da jornada de trabalho sofreu uma inflexão radical. Prevaleceu novamente a lógica imanente ao movimento de "circulação de dinheiro", salientada por Marx, que tende a ampliar a mais-valia absoluta, processo intensificado com a hegemonia do neoliberalismo, "um projeto político de restabelecimento das condições de acumulação do capital e de restauração do poder das elites econômicas" (Harvey, 2008, p. 27). Os ataques violentos e bem-sucedidos ao mundo do trabalho e às suas organizações derivam do fato de que estes haviam se tornado, na década de 1960, "um dos principais obstáculos para o contínuo acúmulo de capital e de consolidação do poder da classe capitalista" (Harvey, 2011, p. 20).
} 
livre está acorrentado ao seu oposto"14. Essa conexão, além de indicar o mote do texto - não é possível inspecionar a destinação atual do tempo livre sem vistoriar a forma de trabalho prevalecente, e vice-versa -, antecipa sua resposta, negativa, à interpelação acerca da exatidão da hipótese de superação da "sociedade do trabalho".

Adorno retoma assim reflexões expostas no ano anterior, na sessão inaugural do $16^{\circ}$ Congresso dos Sociólogos Alemães. Na ocasião, discorreu sobre a temática proposta para o evento, condensada na indagação: "capitalismo tardio ou sociedade industrial?” Em sua explanação, dito de forma breve, ele procurou mostrar que o conceito de capitalismo não era obsoleto (e, por conseguinte, que Marx não estava ultrapassado). Embora o desenvolvimento histórico, invertendo a previsão dos fundadores do materialismo histórico, tenha cristalizado a preponderância das relações de produção sobre as forças produtivas ${ }^{15}$, o diagnóstico geral 120 da doutrina marxista não perdeu sua validade, uma vez que "a dominação sobre seres humanos continua a ser exercida por meio do processo econômico" (Adorno, 1986, p. 67). Adorno (p. 68) complementa sua argumentação, afirmando enfaticamente:

A sociedade é capitalismo em suas relações de produção.

Os homens seguem sendo o que, segundo a análise de

\footnotetext{
${ }^{14}$ Adorno lembra que a expressão "tempo livre", de origem e uso recentes, distingue-se de "ócio", termo que remete ao modo de vida próprio dos cidadãos gregos da Antiguidade. Mais precisamente, a uma condição na qual eles se encontravam desobrigados de qualquer ação diretamente vinculada à sobrevivência material, na síntese de Hannah Arendt (1981, p. 20), uma dispensa "não apenas do labor, que era o modo de vida do escravo, coagido pela necessidade de permanecer vivo e pela tirania do senhor, mas também da vida de trabalho dos artesãos livres e da vida aquisitiva do mercador". Cabe observar que na pauta de atividades da aristocracia europeia, especialmente durante o período de vigência do Antigo Regime, ainda ressoavam ecos, mesmo que distorcidos, desse ócio grego.

15 Adorno (1986, p. 63) destaca que, "em vista do desenvolvimento técnico, as relações de produção se revelaram mais elásticas do que Marx imaginara”.
} 
Marx, eles eram por volta da metade do século XIX:

apêndices da maquinaria, e não mais apenas literalmente os trabalhadores, que têm de se conformar às características das máquinas a que servem, mas, além deles, muitos mais, metaforicamente: obrigados até mesmo em suas mais íntimas emoções a se submeterem ao mecanismo social como portadores de papéis.

A conferência sobre o "tempo livre" destaca e desdobra a ideia - enunciada abruptamente nessa passagem da palestra "Capitalismo tardio ou sociedade industrial?" - de que o predomínio, no âmbito da sociedade moderna, dos papéis sociais na constituição da individualidade confirma a teoria marxista da alienação.

Com um pequeno grão de ironia, Adorno (1995a, p. 70) utiliza os pressupostos da sociologia funcionalista para exemplificar como as pessoas "nem em seu trabalho nem em sua consciência dispõem de si mesmas com real liberdade”. Segundo ele, “mesmo aquelas sociologias conciliadoras que utilizam o conceito de papéis como chave reconhecem isso, enquanto, como sugere essa noção emprestada do teatro, a existência que a sociedade impõe às pessoas não se identifica com o que as pessoas são ou poderiam ser em si mesmas" (Adorno, 1995a, p. 70) ${ }^{16}$.

Nessa perspectiva, submetendo o par antitético "trabalho-tempo livre" a uma avaliação que adota como critério o grau de liberdade experimentado pelos indivíduos no capitalismo, Adorno (1995a, p. 71) reapresenta assim a questão:

\footnotetext{
${ }^{16}$ Adorno (1995a, pp. 70-71) continua a reflexão, ponderando que "decerto não se pode traçar uma divisão tão simples entre as pessoas em si e seus assim chamados papéis sociais. Estes penetram profundamente nas próprias características das pessoas, em sua constituição íntima. Numa época de integração social sem precedentes, fica difícil estabelecer, de forma geral, o que resta nas pessoas, além do determinado pelas funções."
} 
A indagação adequada ao fenômeno do tempo livre seria, hoje, porventura esta: o que ocorre com ele com o aumento da produtividade do trabalho, mas persistindo as condições de não liberdade, isto é, sob relações de produção sob as quais as pessoas nascem inseridas e que, hoje, como antes, lhes prescrevem as regras de sua existência?

Com essa formulação, Adorno reconfigura a discussão acerca da indeterminação suscitada pelos trechos em que Marx, advogando em defesa da regulamentação e da redução da jornada de trabalho, arrola os benefícios que o proletariado poderia desfrutar com a aquisição de tempo hábil para o exercício de outras atividades. A recente experiência histórica, o usufruto em massa do "tempo livre" possibilita um balanço capaz de esclarecer "o que as pessoas fazem com ele e que chances eventualmente oferecem seu desenvolvimento" (Adorno, 1995a, p. 70).

122 Nessa empreitada, na contramão do andamento característico das enquetes da sociologia empírica, Adorno (1995a, pp. 72-73) começa fixando uma premissa teórica geral, na qual transparecem nitidamente suas conclusões:

Quando se aceita como verdadeiro o pensamento de Marx de que na sociedade burguesa a força de trabalho tornouse mercadoria e, por isso, o trabalho foi coisificado, então [...] [apresenta-se] o paradoxo de que aquele estado, que se entende como o contrário de coisificação, como reserva de vida imediata em um sistema total completamente mediado, é, por sua vez, coisificado da mesma maneira que a rígida delimitação entre trabalho e tempo livre.

É possível entrever também nessa declaração de filiação à linhagem do marxismo a forma sob a qual Adorno concebe sua lógica expositiva, encaminhada como a confluência de múltiplas determinações. 
Primeiro, ele descreve a presença de objetivos comerciais nas modalidades mais frequentes de ocupação do tempo livre - dentre as quais o turismo constitui a ocorrência mais notória -, interesses que transformaram a organização dessas atividades num negócio direcionado para a busca de lucro.

O princípio de valorização do capital, subjacente ao processo de "mercantilização" do lazer, por sua vez, impulsionou uma racionalização de procedimentos, sob a forma de "controles sociais suplementares" (Adorno, 1995a, p. 75), que desembocou num paradoxo - a administração do tempo livre. Essa situação, ápice de um movimento de integração social, no entanto, só se tornou possível porque a coação não é apenas externa. Ela assenta-se também, para além do consentimento, numa demanda das pessoas, acostumadas a viver conforme os ditames da não liberdade. Nas palavras de Adorno (1995a, p. 74): “a própria necessidade de liberdade é funcionalizada e reproduzida pelo comércio; o que elas querem lhes é mais uma vez imposto" 17 .

A dominação do econômico manifesta-se até mesmo em seu antípoda. Assim, o tempo livre, a delimitação de uma esfera, por definição, distinta do território e dos procedimentos próprios do mundo do trabalho, de forma contraditória - mas, como lembra Adorno (1995a, p. 73), "precisamente porque é mero apêndice do trabalho" -, cumpre a função de restaurar as energias para a produção. Mais ainda. Algumas atividades do tempo livre servem, mesmo que indiretamente, como preparação dos corpos e dos compor-

\footnotetext{
${ }^{17}$ Essa passagem é antecedida pelo seguinte comentário: "No camping - no antigo movimento juvenil gostava-se de acampar - havia protesto contra o tédio e o convencionalismo burgueses. $\mathrm{O}$ que os jovens queriam era sair, no duplo sentido da palavra. Passar a noite a céu aberto equivalia a escapar da casa, da família. Essa necessidade, depois da morte do movimento juvenil, foi aproveitada e institucionalizada pela indústria do camping. Ela não poderia obrigar as pessoas a comprar barracas e motor-homes, além de inúmeros utensílios auxiliares, se algo nas pessoas não ansiasse por isso" (Adorno, 1995a, p. 74).
} 
tamentos para o exercício profissional. É o caso, segundo Adorno (1995a, p. 79), das práticas esportivas:

Mediante os esforços requeridos pelo esporte, mediante a funcionalização do corpo no team, que se realiza precisamente nos esportes prediletos, as pessoas adestramse sem sabê-lo para as formas de comportamento mais ou menos sublimadas que delas se espera no processo de trabalho. A velha argumentação de que se pratica esporte para permanecer fit é falsa só pelo fato de colocar a fitness como fim em si; fitness para o trabalho é contudo uma das finalidades secretas do esporte.

Adorno acrescenta ainda que a rígida separação, exercida com "zelo puritano", entre trabalho e tempo livre denota um "esquema de conduta próprio do caráter burguês", patente na "moral do trabalho vigente"18. As nor-

124 mas da produção capitalista, interiorizadas pelos indivíduos, prescrevem a maior concentração possível, com a recomendação de "não se distrair, não cometer disparates". Por outro lado, "o tempo livre, provavelmente para que depois se possa trabalhar melhor, não deve lembrar em nada o trabalho. Esta é a razão da imbecilidade de muitas ocupações do tempo livre. Por baixo do pano, porém, são introduzidas, de contrabando, formas de comportamento próprias do trabalho, que não dá folga às pessoas" (Adorno, 1995a, p. 73).

No capitalismo, o "tempo livre" se estabelece, portanto, como uma forma de prolongamento da não liberdade, confirmando a suspeita de que se desenvolve "em direção contrária à de seu próprio conceito, tornando-se paródia deste" (Adorno, 1995a, p. 71). Desse modo, Adorno reitera

\footnotetext{
${ }^{18}$ Adorno contrapõe a essa "rígida divisão da vida em duas metades" sua experiência pessoal e seu modo de vida como intelectual (cf. Adorno, 1995a, p. 72).
} 
o qualificativo que Marx atribuiu ao capitalismo, redefinindo-o como "sociedade do trabalho alienado".

A partir desse diagnóstico, o ensaio-conferência de Adorno procura aquilatar as consequências do fetichismo da mercadoria. Segue assim uma trilha ignorada pelos teóricos da Segunda e da Terceira Internacionais, e destacada, na contramão dessas linhagens, apenas com Lukács (2003 [1923]), em História e consciência de classe. Propõe-se a examinar como a coisificação se alastra a partir da produção e do consumo ${ }^{19}$, atingindo tanto a consciência como o inconsciente dos indivíduos, reificando as atividades no tempo livre e, assim, a própria esfera da vida imediata.

\section{Pseudoatividade}

A observação do modo como os indivíduos se comportam em seu tempo livre configura, assim, um campo de prova privilegiado para a verificação da tese da expansão da reificação até o âmago da vida cotidiana. Os procedimentos mobilizados por Adorno nessa investigação, coordenados ao objetivo de evitar a mera reiteração de princípios genéricos e premissas abstratas, podem ser descritos como uma aplicação meditada de sua proposta de "modelos críticos".

Metodologia sem método, os "modelos críticos" foram apresentados no livro Dialética negativa (Adorno, 2009) como desdobramento necessário de uma teoria concebida como “pensamento de conteúdos". Com essa expressão, Adorno procura indicar que a compreensão intelectual deve mergulhar no heterogêneo, prescindindo da apólice de seguro de categorias dadas de antemão, ou melhor, da técnica usual

\footnotetext{
${ }^{19}$ No capitalismo tardio, "momentos do processo social anteriormente separados, inclusive os seres humanos, são levados a uma espécie de denominador comum. Produção material, distribuição e consumo são administrados conjuntamente. Diluem-se as fronteiras que antes ainda separavam essas esferas correlacionadas no interior do processo global e, com isso, cuidavam do qualitativamente diferenciado" (Adorno, 1986, p. 74).
} 
que subsume aos conceitos apenas o que já estava previamente contido em sua definição. "Modelos críticos" configuram também uma alternativa à exemplificação, modalidade predominante na exposição científica, que tende a reduzir a particularidade à explicitação indiferenciada de um corpus de teoremas ou mesmo de uma fórmula geral.

Adorno intercala em sua conferência reflexões sobre o turismo, o camping, o esporte, o hobby, o hábito de se bronzear, as viagens de férias, as atividades artísticas amadoras, os serviços domésticos etc. A inserção desses conteúdos, sob a forma de breves análises micrológicas, não deixa de promover uma tensão no andamento do texto. Sua incidência interrompe deliberadamente as partes dedicadas à discussão conceitual, impedindo que a especulação se desenrole como um moto contínuo.

$\mathrm{Na}$ indagação, aparentemente inocente, sobre o hobby predileto das pessoas - recorrente, por exemplo, na cobertu126 ra de "celebridades" pela indústria cultural -, Adorno (1995a, p. 74) detecta traços decisivos da ideologia do tempo livre: "Na naturalidade da pergunta sobre qual hobby se tem, está subentendido que se deve ter um, porventura, também já escolhido dentre as ofertas do negócio do tempo livre”. Segundo ele, na manifestação do poder coercitivo que predispõe as pessoas a eleger uma ocupação para preencher as horas em que não se trabalha ressoa a barbárie atual; reafirma-se a não liberdade do indivíduo, resultado de uma integração social regressiva.

Uma combinação paradoxal de atividade e apatia se manifesta na imposição pelo coletivo, sob o risco de causar estranheza, de que se retorne das férias com a pele bronzeada:

Exemplar é o comportamento daqueles que se deixam queimar ao sol, só por amor ao bronzeado e, embora o estado de letargia a pleno sol não seja prazeroso de maneira nenhuma, e talvez desagradável fisicamente, o certo é que torna as pessoas espiritualmente inativas. $\mathrm{O}$ caráter fetichista 
da mercadoria se apodera, por meio do bronzeado da pele - que, de resto, pode cair muito bem - das pessoas em si; elas se transformam em fetiches para si mesmas. [...] O bronzeado tornou-se um fim em si, mais importante que o flerte para o qual talvez devesse servir em princípio (Adorno, 1995a, pp. 74-75) ${ }^{20}$.

O desfrute do tempo livre, sobretudo quando este se configura como o oposto estrito do trabalho, redunda, por conseguinte, muitas vezes, precisamente naquilo que se deseja evitar: rotina, apatia e tédio. Um sempre igual que não se dissipa sequer, como o ennui de Baudelaire, com o distanciamento proporcionado por paragens ou paisagens exóticas e que decorre, em última instância, da situação de heteronomia do indivíduo.

O tédio existe em função da vida estar regulada pela coação do trabalho e por uma rigorosa divisão do trabalho. Não teria necessariamente que existir. Sempre que a conduta no tempo livre é verdadeiramente autônoma, determinada pelas próprias pessoas enquanto seres livres, é difícil que se instale o tédio; tampouco ali onde elas perseguem seu anseio de felicidade, ou onde sua atividade no tempo livre é racional em si mesma, como algo em si pleno de sentido. [...] Se as pessoas pudessem decidir sobre si mesmas e sobre suas vidas, se não estivessem encerradas no sempre-igual então não se entediariam (Adorno, 1995a, p. 76).

A noção de "heteronomia", no entanto, não é concebida em registro abstrato, como mera categoria filosófica.

\footnotetext{
${ }^{20}$ Com a disseminação da informação de que a exposição prolongada ao sol pode ser uma das causas do câncer de pele, esse hábito, generalizado durante o século passado, arrefeceu. A fetichização do corpo, destacada por Adorno, apenas mudou de endereço. Pode ser encontrada em novos cuidados, presentes, por exemplo, na febre de modelação corporal em academias de ginástica.
} 
Trata-se de uma determinação histórica, característica da situação do indivíduo na sociedade capitalista. Nas palavras de Adorno (1995a, p. 76): "Em íntima relação com o tédio está o sentimento, justificado ou neurótico, de impotência: tédio é o desespero objetivo. Mas ao mesmo tempo, também a expressão de deformações que a constituição global da sociedade produz nas pessoas".

Dentre essas mutilações, ele ressalta a desvalorização e o subsequente atrofiamento das potencialidades da imaginação:

A fantasia torna-se tão suspeita quanto a curiosidade sexual e o anseio pelo proibido, assim como dela desconfia o espírito de uma ciência que não é mais espírito. Quem quiser adaptar-se deve renunciar cada vez mais à fantasia. Em geral, mutilada por alguma experiência da primeira infância, nem consegue desenvolvê-la. A falta de fantasia, implantada e insistentemente recomendada pela sociedade, 128 deixa as pessoas desamparadas em seu tempo livre. [...] Que efetivamente as pessoas consigam se beneficiar tão pouco de seu tempo livre se deve a que, de antemão, já lhes foi amputado o que poderia tornar prazeroso o tempo livre. Tanto ele lhes foi recusado e difamado que já nem o querem mais (Adorno, 1995a, pp. 76-77).

Na configuração social vigente, com o atrofiamento da capacidade criativa, as atividades artísticas de tempo livre nunca ultrapassam a condição de imitações de obras de arte. A qualidade inferior de seus produtos, que "estraga a alegria do trabalho" (Adorno, 1995a, p. 77), decorre tanto do amadorismo e da ausência de inserção na divisão intelectual do trabalho como das dificuldades inerentes ao domínio técnico e à invenção artística.

Apesar de supérfluas, tais atividades também se encontram socialmente integradas, situação mais visível no caso da ocupação do tempo livre em serviços domésticos, que supre 
a carência de empregados encarregados de realizar atividades outrora consideradas subalternas. Na orientação prática inscrita no lema "do it yourself", Adorno (1995a, p. 78) observa que "novamente no interesse de indústrias especializadas, [as pessoas] são encorajadas a fazer elas mesmas o que outros poderiam fazer por elas melhor e mais facilmente e, que, no fundo, por isso mesmo elas têm que desdenhar".

As atividades de tempo livre distribuem-se, portanto, num espectro delimitado, num extremo, pela apatia e, no outro, pela pseudoatividade, polos imbricados, segundo Adorno, num nexo necessário. Com o bloqueio das possibilidades de mudança das "relações fossilizadas", e dada a dificuldade dos indivíduos em aceitar essa aporia, proliferam "atividades aparentes, ilusórias": "pseudoatividade são ficções e paródias daquela produtividade que a sociedade, por um lado, reclama incessantemente e, por outro lado, refreia e não quer muito nos indivíduos" (Adorno, 1995a, pp. 78-79).

Adorno (2008) já havia utilizado o termo "pseudoatividade" num aforismo, o 84, de Minima moralia (publicado em 1947). Lá - após estabelecer a distinção entre o modo de vida do intelectual e o do burguês a partir da recusa do primeiro em aderir à alternativa "trabalho ou diversão" -, atribui a intolerância coletiva perante a "fusão de prazer e trabalho" ao avanço da atomização, presente não só na sociedade "como também no indivíduo singular, em suas esferas vitais". Essa partilha do indivíduo contemporâneo em funções independentes entre si demanda uma busca, desesperada, por substitutivos.

Enquanto o trabalho e o divertimento cada vez se assemelham mais na estrutura, com tanto mais rigor eles são apartados por linhas de demarcação invisíveis. De ambos o prazer e o espírito foram igualmente expulsos. Em um como no outro regem a seriedade bovina e a pseudoatividade (Adorno, 2008 [1947], p. 127). 
O conceito de pseudoatividade reaparece, com destaque, no ensaio "Notas marginais sobre teoria e práxis". Nesse artigo, redigido em 1969 e coligido em Stichworte, o termo designa um comportamento generalizado - a práxis ilusória moldada pelas estratégias de autoconservação ${ }^{21}$-, mas também uma ação específica. Na maior parte das ocorrências, seu uso qualifica o ativismo (segundo Adorno, mera mimese do gestual revolucionário) que germinou na Europa no final dos anos $1960^{22}$.

Trata-se de uma reação às condições sociais objetivas, à situação de huis clos, caracterizada pela obstrução das saídas, pela aversão e impermeabilidade à teoria e ao conhecimento, pelo bloqueio ou pela ausência de experiências, pela "involução subjetiva". Segundo Adorno (1995b, pp. 203-204), a falsa práxis, "danificada e por isso, ansiada, desfigurada, desesperadamente supervalorizada”, não constitui mais que "satisfações compensatórias institucionalizadas" que desviam e desorientam a espontaneidade.

Assim como a personalização é um falso consolo diante do fato de que o indivíduo carece de importância no mecanismo anônimo, do mesmo modo a pseudoatividade constitui um engano em relação à despotenciação de uma práxis que pressupõe um agente livre e autônomo, que já não mais existe (Adorno, 1995b, pp. 217-218).

Esse agente, encarnado, durante o período de vida de Marx, no proletariado europeu, teve sua autonomia e liberdade reduzidas com o desenvolvimento das forças produtivas

\footnotetext{
21 "Enquanto a práxis promete guiar os homens para fora do fechamento em si, ela mesma tem sido, agora e sempre, fechada [...]. Até se poderia perguntar se até hoje, toda práxis, enquanto domínio da natureza, não tem sido, em sua indiferença frente ao objeto, práxis ilusória" (Adorno, 1995b, p. 202).

22 "O ativismo submete-se à mesma tendência que acredita (ou pretende) combater: o instrumentalismo burguês, que fetichiza os meios porque a reflexão sobre os fins se torna intolerável para o tipo de práxis que lhe é próprio" (Adorno, 1995b, p. 217).
} 
técnicas e a ampliação da acumulação capitalista. Sua submersão à reificação, intensificada em todas as instâncias da vida, pode ser atestada por sua atuação recente na esfera pública, uma pauta que oscila entre a apatia e a pseudoatividade.

A atribuição, por Adorno, das mesmas qualificações às ocupações do tempo livre e à ação política não é casual. Num trecho da conferência-ensaio de maio de 1969, ele aponta para a semelhança dos sentimentos que presidem tanto o tédio como a indiferença em relação à vida pública:

Tédio é o reflexo do cinza objetivo. Ocorre com ele algo semelhante ao que se dá com a apatia política. A razão mais importante para essa última é o sentimento das massas, de nenhum modo injustificado, de que com a margem de participação na política que lhes é reservada pela sociedade pouco podem mudar em sua existência, bem como, talvez, atualmente em todos os sistemas do planeta. O nexo entre a política e seus próprios interesses lhes é opaco, por isso recuam diante da atividade política (Adorno, 1995a, p. 76).

A aposta de Marx na possibilidade de uma transição ao comunismo através de uma revolução capitaneada pelo proletariado assentava-se em larga medida na capacidade de organização dos trabalhadores, demonstrada inúmeras vezes ao longo do século XIX. No texto em que esse crédito é maximizado - o Manifesto do Partido Comunista -, ele apresenta o proletariado como um sujeito histórico que, a despeito de uma série de entraves, conseguiu constituir-se como partido político e classe revolucionária (cf. Musse, 2010).

Marx lista como obstáculos à emancipação do proletariado a sua condição de mercadoria, a concorrência dos indivíduos para obter ou manter seus empregos, a submissão dos trabalhadores no espaço da produção ao despotismo da cooperação capitalista, a reificação no âmbito do trabalho e fora dele etc. Nem assim sua confiança na 
ação transformadora da classe operária, presente em sua obra desde 1843 e mantida, embora com menor ênfase, após os acontecimentos de 1848, sofreu abalos. A firmeza de sua convicção explica em parte a ambiguidade que inflou as expectativas de que a redução da jornada de trabalho viesse a favorecer a organização e o poder social do proletariado.

Em várias passagens e em diferentes momentos de sua obra, Adorno defende a atualidade da teoria marxista das classes sociais $^{23}$. Em geral, adverte ele, as tentativas de refutação dessa formulação partem da suposição equivocada de que as classes são delimitadas no âmbito da consciência. No marxismo, no entanto, a determinação das classes sociais depende de sua posição objetiva no processo produtivo, da propriedade (ou da capacidade de dispor) dos meios de produção. Uma vez que o próprio Marx concebeu a consciência de classe como um epifenômeno, a integração do proletariado nas sociedades industrializadas do Hemisfério

132 Norte não indica que essa classe tenha desaparecido.

No entanto, ao mesmo tempo, Adorno reitera o diagnóstico proposto por Horkheimer nos anos 1930. Na enunciação da primeira teoria crítica, este, privilegiando a descrição do marxismo como "tradição intelectual", reconhece o papel de protagonista do proletariado apenas durante a gênese e a formação do materialismo histórico, desvinculando a doutrina e os desdobramentos da teoria das vicissitudes de sua práxis (cf. Horkheimer, 1983, pp. 134-36). Esse desengate permite que Adorno (2008, pp. 109-10), em Minima moralia, por exemplo, possa afirmar peremptoriamente, sem se desfiliar da linhagem marxista, que o proletariado "cada vez mais se limita meramente a refletir as tendências de desenvolvimento do capitalismo".

Na conferência-ensaio sobre o tempo livre, Adorno reitera a persistência da situação de não liberdade na órbita

${ }^{23}$ Ver, por exemplo, Adorno (1972a [1942]; 1972b [1956]; 1986 [1968]). 
do trabalho, apontada por Marx. Considera infundadas, no entanto, as expectativas do fundador do materialismo histórico de que o tempo adicional obtido pelo proletariado com a redução da jornada de trabalho resultaria em um incremento de sua atividade política.

Segundo Adorno, a prevalência da reificação em todas as esferas da vida teria contribuído decisivamente para que a integração do proletariado, concomitante à implementação do planejamento econômico capitalista, atingisse seu ápice na sociedade administrada. Ele destaca ainda que a progressiva adequação do proletariado à ordem social foi impulsionada também pela metamorfose do tempo livre em uma modalidade inconsciente de adestramento dos indivíduos que os prepara, num ritmo cada vez mais intensificado, para o trabalho.

\section{Ricardo Musse}

é livre-docente do Departamento de Sociologia da Faculdade de Filosofia, Letras e Ciências Humanas da Universidade de São Paulo (FFLCH-USP), e um dos coordenadores do Laboratório Karl Marx da FFLCH-USP.

\section{Bibliografia}

ADORNO, T. W. 1972a [1942]. Reflexionen zur Klassentheorie. In:

Soziologische Schriften. Frankfurt a.M.: Suhrkamp. . 1972b [1956]. Über Statik und Dinamik als soziologische

Kategorien. In: Soziologische Schriften. Frankfurt a.M.: Suhrkamp. . 1980. Stichworte: Kritische Modelle 2. Frankfurt a.M.: Suhrkamp. 1986. Capitalismo tardio ou sociedade industrial?. In: COHN, G.

(org.). Theodor W. Adorno. São Paulo: Ática. 1995a. Tempo livre. In: Palavras e sinais: modelos críticos 2.

Petrópolis: Vozes. 1995b. Notas marginais sobre teoria e práxis. In: Palauras e

sinais: Modelos críticos 2. Petrópolis: Vozes. 2008 [1947]. Minima moralia. Rio de Janeiro: Azougue. 2009. Dialética negativa. Rio de Janeiro: Zahar.

ARENDT, H. 1981. A condição humana. Rio de Janeiro: Forense

Universitária. 
HARVEY, D. 2008. O neoliberalismo: história e implicações. São Paulo: Loyola. . 2011. O enigma do capital e as crises do capitalismo. São Paulo: Boitempo.

HORKHEIMER, M. 1983. Teoria tradicional e teoria crítica. In:

Textos escolhidos. São Paulo: Abril Cultural.

LUKÁCS, G. 2003 [1923]. História e consciência de classe. São Paulo: Martins Fontes.

MARCUSE, H. 1972. Novas fontes para a fundamentação do materialismo histórico. In: . Ideias sobre uma teoria crítica da sociedade. Rio de Janeiro: Zahar. 1978. Razão e revolução. Rio de Janeiro: Paz e Terra.

MARX, K. 1977. Crítica ao programa de Gotha. In: Textos. São

Paulo: Edições Sociais. 1978 [1859]. Para a crítica da economia política. São Paulo: Abril

Cultural. 1984 [1867]. O capital. São Paulo: Abril Cultural. 2004 [1844]. Manuscritos econômico-filosóficos. São Paulo: Boitempo. . 2010a [1848]. Manifesto do Partido Comunista. São Paulo: Hedra. . 2010b. Manuscritos de 1861-1863, cadernos I a IV. Belo Horizonte:

Autêntica.

2011. Grundrisse. Manuscritos econômicos de 1857-1858: Esboços da crítica da economia política. São Paulo: Boitempo/Ed. UFRJ.

MARX, K.; ENGELS, F. 1983. Gesamtausgabe. Berlin: Dietz.

MUSSE, R. 2010. Introdução ao Manifesto comunista. In: MARX, K.

Manifesto do Partido Comunista. São Paulo: Hedra.

PIERUCCI, A. F. 2003. O desencantamento do mundo: todos os passos do conceito em Max Weber. São Paulo: Editora 34.

ROSDOLSKY. R. 2001. Gênese e estrutura de O Capital. Rio de Janeiro: EDUERJ/ Contraponto.

WEBER, M. 1971. Rejeições religiosas do mundo e suas direções. In: . Ensaios de sociologia. Rio de Janeiro: Zahar. . 1972. A ciência como vocação. São Paulo: Cultrix. 1996 [1920]. Introdução. In: - A ética protestante e o espírito do capitalismo. Lisboa: Editorial Presença. . 2004. A ética protestante e o "espírito" do capitalismo. São Paulo:

Companhia das Letras. 


\section{A ADMINISTRAÇÃO DO TEMPO LIVRE}

\section{RICARDO MUSSE}

Resumo: A conferência de Theodor W. Adorno sobre o conceito e a prática do "tempo livre", publicada em Stichworte, em 1969, foi proferida numa época de pleno emprego. A gradativa redução da jornada normal de trabalho, sinalizando e consolidando uma tendência de longo prazo, inspirou uma série de conjecturas acerca de uma possível mudança nas estruturas até então assentadas como próprias do mundo moderno. Nesse contexto, a conferência-ensaio de Adorno organiza-se, ao mesmo tempo, como uma atualização e como um comentário das considerações de Karl Marx sobre a situação do trabalho no capitalismo. Remete também, ainda que em menor medida, às ponderações de Max Weber que se tornaram um dos pomos de discórdia na controvérsia a respeito da obsolescência ou não do paradigma da "sociedade do trabalho.

Palavras-chave: Theodor Adorno; Karl Marx; Tempo Livre; Jornada de Trabalho; Sociedade do Trabalho; Capitalismo.

\section{FREE TIME ADMINISTRATION}

Abstract: The conference of Theodor W. Adorno on the concept and practice of "free time", published in Stichworte (1969), was delivered at a time of full employment. The gradual reduction of the normal working hours which suggested and consolidated a long-term tendency, has inspired several conjectures about structures hitherto regarded as inherent to the modern world. Hence, Adorno's conference-essay organizes itself both as an update and as a comment of Karl Marx's considerations about labor in capitalism. It also refers, although with less emphasis, to Max Weber's considerations that have become a bone of contention about the obsolescence or not of the "work society" paradigm. 
Resumo / Abstract

Keywords: Theodor Adorno; Karl Marx; Free Time; Working Hours; Work Society; Capitalism.

Recebido: 13/11/2013 Aprovado: 07/10/2016 